\title{
Ticks (Acari: Ixodida) on birds (Aves) migrating through the Polish Baltic coast
}

\section{Olaf Ciebiera $^{1}$ D $\cdot$ Leszek Jerzak ${ }^{1} \cdot$ Magdalena Nowak-Chmura $^{2} \cdot$ Marcin Bocheński $^{1}$}

Received: 23 August 2018 / Accepted: 4 February 2019 / Published online: 15 February 2019

(c) The Author(s) 2019

\begin{abstract}
Seasonal bird (Aves) migration between breeding and wintering areas, often located on different continents, can facilitate the spreading of tick species (Acari: Ixodida) and of tickborne pathogens. The aim of the study was to analyse the occurrence of ticks dispersed by birds migrating along the Polish Baltic coast during spring and autumn migration. Field research was conducted at the bird ringing station in Wicie, located on the middle of the Polish Baltic coast, in 2011 and 2012 during spring and autumn migration. A total of 2657 birds from 45 species was examined. The most common species inspected were European robin (Erithacus rubecula) (63.3\%), song thrush (Turdus philomelos) (5.13\%), and goldcrest (Regulus regulus) (4.5\%). Overall, 3129 ticks belonging to six species were collected: Ixodes ricinus (1650 larvae, 1390 nymphs and 1 male), Ixodes frontalis (20 larvae, 20 nymphs), Ixodes arboricola (35 larvae), Dermacentor reticulatus (1 larva), and Haemaphysalis punctata ( 1 nymph). Ten larvae and one nymph could only be identified to the genus level Ixodes. Ticks were located on various parts of the head: on the corner of the beak $(75.0 \%)$, near the eyes $(14.6 \%)$, on the chin $(4.4 \%)$, near the ears $(4.4 \%)$, on the neck $(1.1 \%)$, and in the beak $(0.5 \%)$. The overall tick prevalence was $40.5 \%$. The highest prevalence was for bird species feeding on the ground, covering a medium distance to wintering grounds and migrating at night. Statistically significant differences between the number of ticks and the sex of the host species were detected in blackbirds: males carried more parasites than females, both, during spring and autumn migration. The fact that I. ricinus and other ticks parasitize birds migrating through Poland extends the possibility of the spread of tick-borne diseases.
\end{abstract}

Keywords Ticks $\cdot$ Ixodida $\cdot$ Migratory birds $\cdot$ Poland $\cdot$ Migration routes $\cdot$ Baltic Sea

Olaf Ciebiera

o.ciebiera@wnb.uz.zgora.pl

1 Faculty of Biological Sciences, University of Zielona Góra, Prof. Z. Szafrana Str. 1, 65-516 Zielona Góra, Poland

2 Department of Invertebrate Zoology and Parasitology, Institute of Biology, Pedagogical University of Cracov, Podbrzezie Str. 3, 31-054 Kraków, Poland 


\section{Introduction}

The migratory behaviour of birds is one the most spectacular and incredible natural events. About 5 billion birds from circa 200 species undertake their journeys between the Western Palearctic and Afrotropic ecozones annually (Berthold 2001; Newton 2008). Poland is located in a unique position, because, two migratory pathways intersect. Some bird populations from the Scandinavian Peninsula fly across the Baltic Sea and Poland, selecting the Eastern migratory route across the Bosphorus Strait to the South. Others fly from NorthEastern Europe alongside the Baltic coast selecting the Western migratory route via the Gibraltar Strait (Berthold 2001; Newton 2008).

Birds can carry various types of ectoparasites, such as bird lice (Mallophaga) or quill mites (Acari: Prostigmata: Syringophilidae) for thousands of kilometers (Daniel et al. 1997). Long term, regular bird migration research shows that particular species and life stages of ticks (Acari: Ixodidae) are also transported over long distances and across geographical barriers. The biggest proportion are larvae and nymphs (Nuorteva and Hoogstraal 1963; Hoogstraal at al. 1963, 1964; Kahl 1971; Walter et al. 1979; Špitalská et al. 2006; Nowak-Chmura 2012). The prevalence of tick infestation may reach $60 \%$ of migrating birds depending on the species (Nuorteva and Hoogstraal 1963; Hoogstraal at al. 1963, 1964). Because of parasitic spreading and (probably) climate change, the probability of occurrence of new parasitic species in natural fauna and consequent spreading zoonosis may increase (Gray et al. 2009; Fuller et al. 2012).

The aim of this paper was to analyse tick distribution on birds during spring and autumn migration along the Polish Baltic coast, the estimation of host specificity for particular tick species of different life stages and the estimation of intensity of infestation. The scope of the paper includes an assessment of tick localization on birds and an investigation of whether the feeding preference, migration distance and the diurnal rhythm of migration of different bird species influences tick encumbrance. The paper also examines tick infestation according to bird sex. The potential impact on tick borne pathogens is described in another paper (Ciebiera et al. in preparation).

\section{Materials and methods}

\section{Sample collection}

Birds were trapped during migration at the "Fundacja Wspierania Badań nad Wędrówkami Ptaków" (Bird Migration Research Foundation) ringing station. Field work was conducted in Wicie Village on the Polish Baltic Coast (N: 54²9'54,29", E: 16²7'31,04") during four migratory seasons: two spring seasons: from 07 to 12 April 2011 and 15 to 21 April 2012 and two autumn seasons: from 22 to 27 September 2011 and 24 to 28 October 2012. The ringing site is situated on the bird migratory routes across the Baltic Sea between the breeding areas in Northern Europe and the wintering areas in Southern Europe and Africa. Research on migratory species has been conducted in this region since the 1960s (Busse 2005). During all seasons, about 450 linear metres of nets with mesh size $16 \mathrm{~mm}$ were used, usually placed in the same locations. The field work followed the standard protocol used by Operation Baltic and the SEEN network described in Zaniewicz and Rosińska (2015) and Busse (2000). All nets were checked every hour from dusk to dawn. After species determination, the caught birds were aged and sexed (if possible) according to plumage 
features (Busse 1984; Svensson 1992), then ringed, and measured. The data collected included the level of fat deposits on a 9-point scale, wing and tail length, wing formula, and weight to the nearest $0.1 \mathrm{~g}$. Afterwards, each bird was carefully inspected for the presence of ticks. All feeding ticks were removed by fine forceps and placed in an Eppendorf tube filled with $70 \%$ ethanol. Each tube was labelled with the individual bird ring number. The number of ticks and the place where it was feeding on the bird were also recorded. No bird was injured or died during the study. Ticks were sorted in the laboratory in the Faculty of Biological Sciences, University of Zielona Góra, where each tick was cleared and put in individual labeled tubes. Species or genus and life stage were determined by the use of a dichotomous key described in Siuda (1993). For a full identification, a binocular microscope was used. After determining the species, each tick was then stored in a labelled tube with $70 \%$ ethanol for further epidemiological analysis. Recaptured birds were excluded from analysis. All bird species were divided into three ecological groups according to their feeding preferences during migration: Type 0 - species which mainly feed on the ground or in low parts of plants, Type 1-species which feed in bush and shrubs and Type 2-species, which feed in the canopy of trees. Each bird species was also assigned to a migratory distance group (sedentary/local, medium and long) and a diurnal/nocturnal group (del Hoyo et al. 2017; Swiss Ornithological Institute 2018) (see Tables 1,2). Birds species considered as sedentary/local migrants usually stay all year in the same region or migrate only short distances-usually do not reach the Mediterranean region from Poland for wintering (del Hoyo et al. 2017; Swiss Ornithological Institute 2018). The medium distance birds reach the Mediterranean region, and the long distances group continue to central and southern Africa for wintering (del Hoyo et al. 2017; Swiss Ornithological Institute 2018).

\section{Bird sex and probability of ticks infestation}

Five bird species were chosen for analysis of the relationship between the sex of the birds and the infestation rates: Cyanistes caeruleus, Parus major, Regulus regulus, Sylvia atricapilla and Turdus merula. These bird species exhibit sexual dimorphism in both juvenile and adult life stages and the number of birds trapped allowed statistical analysis.

\section{Statistical analysis}

Statistical analysis was performed by Statistica 10 Software and Excel 2010. Statistical tests were used according to Zar (1999).

\section{Results}

During four migration seasons 2657 birds of 45 species were captured (Tables 1, 2). 3129 ticks were collected from 1076 birds of 25 species, giving a prevalence of $40.5 \%$ of the total individuals examined. A mean of 2.9 ticks was recovered per infested bird. In total, 1716 larvae, 1412 nymphs and 1 adult male tick were collected. The dominant species was Ixodes ricinus (L.) (1650 larvae, 1390 nymphs, 1 adult male) followed by Ixodes frontalis (Panzer) (20 larvae, 20 nymphs), Ixodes arboricola Schulze et Schlottke (35 larvae), Dermacentor reticulatus (Fabricius) (1 larva) and Haemaphysalis punctata Canestrini et Fanzago (1 nymph). A further 10 larvae and 1 nymph were determined as Ixodes sp. Morphological characteristics of four individual larvae from this group were very similar to Ixodes 


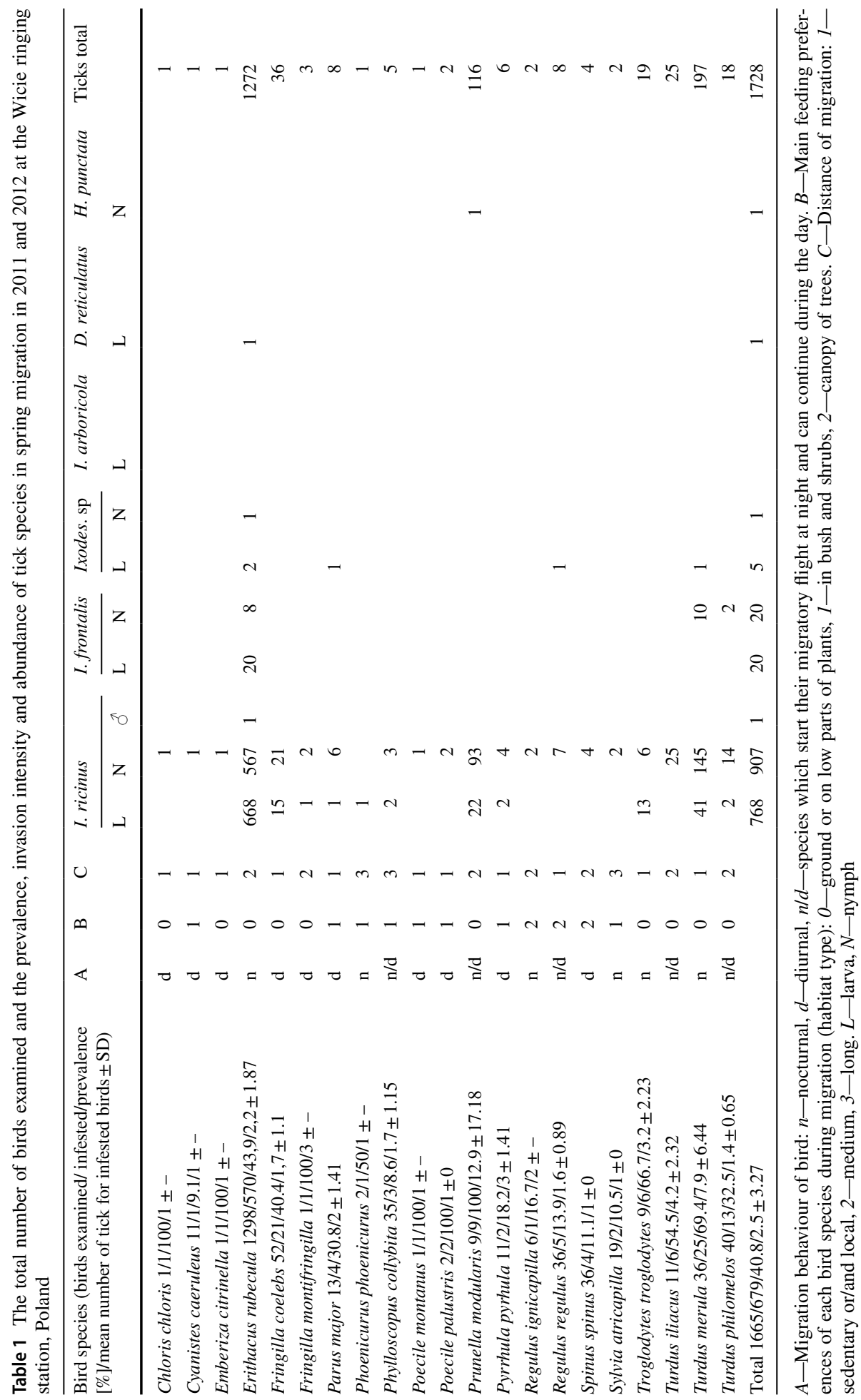




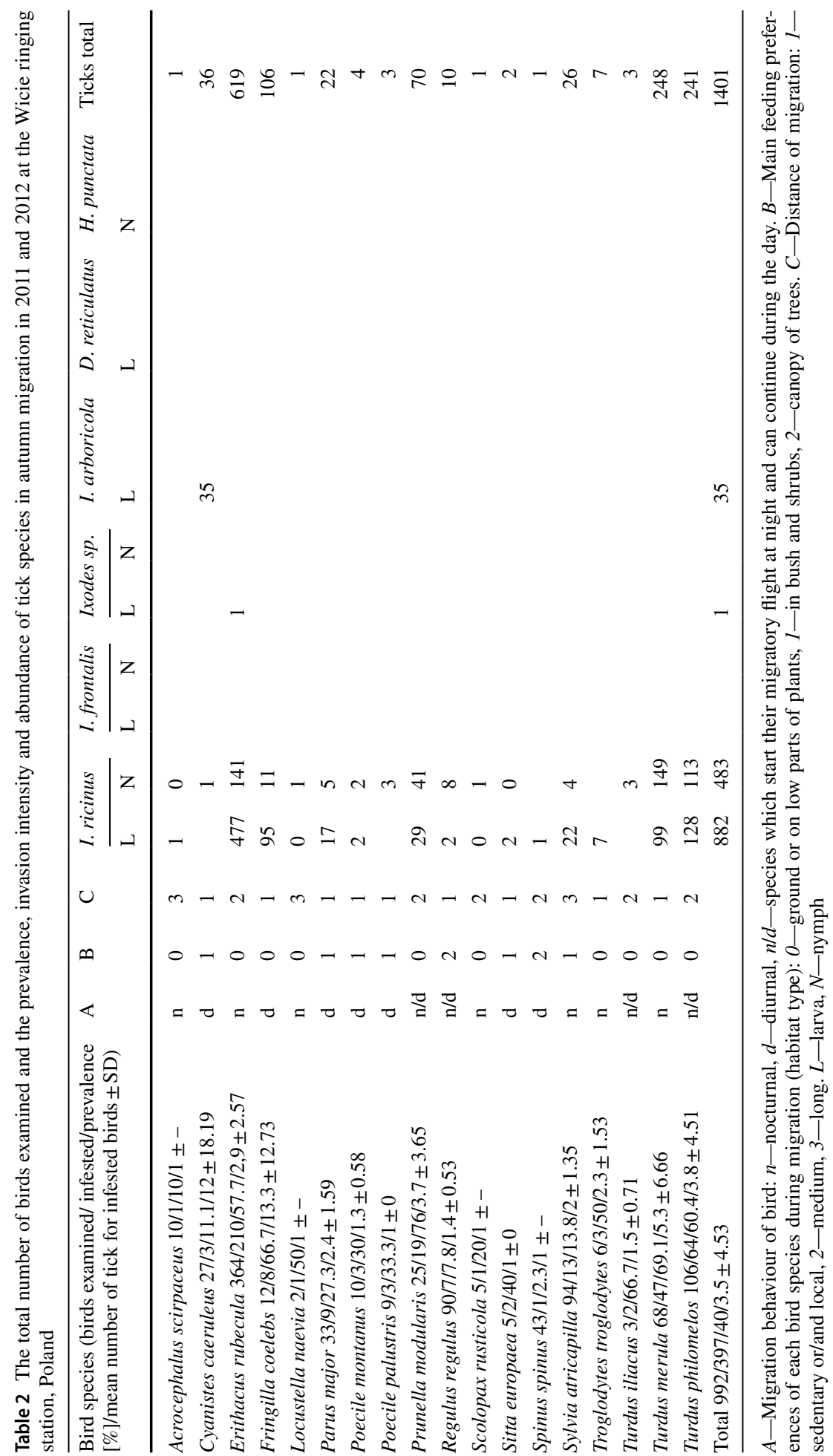


caledonicus Nuttall, but this needs further investigation (those individuals were included in the Ixodes sp. group).

Tick distribution was fractionally different between the spring and autumn migration. In spring 1665 birds of 31 species were captured and 1728 ticks were collected from 679 infested birds of 21 species (Table 1). 10 bird species carried no ticks (birds individuals checked): Accanthis flammea (1), Aegithalos caudatus (1), Alcedo atthis (1), Certhia familiaris (2), Dendrocopos major (1), Emberiza schoeniclus (6), Luscinia svecica (1), Periparus ater (3), Phylloscopus trochilus (18) and Sittta europaea (1). The tick prevalence was $40.7 \%$ of birds examined and the mean intensity was 2.5 ticks per bird. Tick species diversity was 1676 (768 larvae, 907 nymphs, 1 adult male) I. ricinus, 40 (20 larvae, 20 nymphs) I. frontalis, 6 (5 larvae, 1 nymph) Ixodes sp., 1 D. reticulatus larva and $1 \mathrm{H}$. punctata nymph.

In autumn 992 birds of 40 species were captured and 1401 ticks were collected from 397 infested birds of 18 species (Table 2). 22 bird species carried no ticks (birds individuals checked): Acrocephalus schoenobaenus (1), Aegithalos caudatus (17), Anthus trivialis (1), Asio flammeus (1), Asio otus (1), Bombycilla garrulus (1), Certhia familiaris (7), Coccothraustes coccothraustes (1), Emberiza citrinella (2), Emberiza schoeniclus (4), Fringilla montifringilla (1), Gallinago gallinago (4), Hirundo rustica (1), Locustella fluviatilis (1), Lophophanes cristatus (2), Periparus ater (2), Phoenicurus phoenicurus (1), Phylloscopus collybita (15), Phylloscopus trochilus (6), Pyrrhula pyrrhula (6), Regulus ignicapilla (1) and Sylvia borin (8). The tick prevalence was $40.0 \%$ of birds examined and the mean intensity was 3.5 ticks per bird. Tick species diversity was 1365 (882 larvae, 483 nymphs) I. ricinus, 35 I. arboricola larvae and 1 larva of Ixodes sp.

As stated above, during spring migration, a total of 1728 ticks was collected: 929 (53.8\%) nymphs, $798(46.2 \%)$ larvae and $1(0.1 \%)$ adult male. During autumn migration, a total of 1401 ticks was collected: 483 (34.5\%) nymphs and 918 (65.5\%) larvae. There was no significant difference between the prevalence of ticks in birds migrating in spring and in autumn $\left(\chi^{2}=0.15 ; \mathrm{df}=1 ; \mathrm{p}=0.69\right)$, while differences in abundance of tick stages (excluding 1 adult male) were statistically significant $\left(\chi^{2}=116.56\right.$; $\left.\mathrm{df}=1 ; \mathrm{p}<0.001\right)$.

The probability of parasitism by ticks was significantly higher in the medium distance migrants (2) than in local/sedentary and long-distance migrants $\left(\chi^{2}=119.05 ; \mathrm{df}=2\right.$; $\mathrm{p}<0.001$ ). When the same analysis was conducted excluding E. rubecula (which was superdominant in medium distance migrants) the analysis nevertheless confirmed the highest probability of parasitism in this group $\left(\chi^{2}=55.35\right.$; $\mathrm{df}=2$; $\left.\mathrm{p}<0.001\right)$.

The prevalence was significantly higher in bird species feeding on the ground and in the lower parts of plants (habitat type 0$)$, than in other habitat groups $\left(\chi^{2}=255.15 ; \mathrm{df}=2\right.$; $\mathrm{p}<0.001)$.

Nocturnal migrants had a higher prevalence of tick infestation than diurnal migrants and species that start their migratory flight at night and continue during the day $\left(\chi^{2}=73.124\right.$; $\mathrm{df}=2 ; \mathrm{p}<0.001)$.

Four bird species were chosen for the analysis of tick prevalence with respect to bird sex (P. major, $R$. regulus, $S$. atricapilla and $T$. merula). There was a significant difference between tick prevalence and sex for $T$. merula but not for the other three species (P. major $\left(\chi^{2}=0.22 ; \mathrm{df}=1 ; \mathrm{p}=0.64\right), R$. regulus $\left(\chi^{2}=0.33 ; \mathrm{df}=1 ; \mathrm{p}=0.56\right)$, S. atricapilla $\left(\chi^{2}=0.09 ;\right.$ $\mathrm{df}=1 ; \mathrm{p}=0.75)$. Male T. merula were more frequently infested with ticks $\left(\chi^{2}=10.93\right.$; $\mathrm{df}=1 ; \mathrm{p}<0.001)$ than females and this was true both, for spring $\left(\chi^{2}=10.93 ; \mathrm{df}=1\right.$; $\mathrm{p}<0.001)$ and autumn $\left(\chi^{2}=5.92 ; \mathrm{df}=1 ; \mathrm{p}<0.05\right)$.

All ticks were localized on the birds' heads: $75.0 \%$ (2346 individuals) on the corner of the beak, $14.6 \%$ (458 individuals) on the eye ring, 4.4\% (138 individuals) on the chin, $4.4 \%$ 
(139 individuals) on the ear opening, $1.1 \%$ (33 individuals) on the nape and $0.5 \%$ (15 individuals) inside the beak.

\section{Discussion}

During seasonal migration between the Western Palearctic and Afrotropic ecozones, birds have direct contact with several specific environments from tundra and taiga in the North to savannah and tropical forests in the South. Those specific habitats are also living places for many tick species. Some of the latter are closely or casually associated with migrating birds, which also play a fundamental role in the global dispersal of these ectoparasites (Hasle 2013). The dispersal of ticks over long distances can be influenced by bird species, their migratory distance, migration speed and their migration route. Migratory speed is faster in spring when birds are returning to breeding areas. For example, the spring migration of blackcap S. atricapilla from Mid-Africa to Northern Europe takes approximately 34 days (Mikula et al. 2011). The migratory speed for robin E. rubecula is circa $100 \mathrm{~km} /$ day (del Hoyo et al. 2017). On the other hand, feeding by ticks can take from a few hours to several weeks depending on the tick species and the stage in its life cycle. The dispersal of ticks beyond their normal range is a common phenomenon, but rarely confirmed (Siuda and Dutkiewicz 1979; Siuda and Szymański 1991; Laakkonen et al. 2009). Our study showed that bird species that perform a medium distance migration play a significant role in tick dispersal in comparison to short and long distant species. Other studies from Europe also confirmed that medium-distant birds have the highest prevalence of ticks (Nuorteva and Hoogstraal 1963; Mikula et al. 2011; Gryczyńska 2002; Kjelland et al. 2010; Ciebiera and Jerzak 2011; Hasle et al. 2011).

In this study, bird species were divided into three groups: nocturnal migrants, diurnal migrants and species that start their migratory flight at night and continue during the day. The tick circadian rhythm related to the daily light cycle, the changes in temperature, and differ in relation of latitude on bird migratory routes. Our study confirmed that night migrants are associated with a higher prevalence of ticks than those species that only migrate by day. This may have a direct casual connection with tick circadian activity. Peaks of circadian activity of I. ricinus in Poland occurred between 23:00-24:00 and 8:00-9:00 (Nowak et al. 2009). Presumably, night migrants are more exposed to ticks during their morning peak activity when feeding, than either day or night/day migrants are.

Generally, nocturnal migratory birds carried more ticks than diurnal and night/daily migrants. This phenomenon might be important for the transfer of ticks (and associated pathogens) among migratory stop-overs, but more multifaced studies are required to clarify this.

Five tick species were found on migratory birds on the Polish Baltic Coast in 2011 and 2012. Ixodes ricinus was the most abundant species of tick on migratory birds during the study. The northward, spring migration is characterized by a higher number of this tick species and a higher number of nymphs compared to the southward, autumn migration (Siuda 1993; Nowak-Chmura et al. 2012; Hornok et al. 2014a, b; Sándor et al. 2014). Ixodes ricinus is one of the most abundant tick species in central Europe (Hasle et al. 2009). Considering that the majority of larvae and nymphs were in an initial feeding phase, these ticks probably came from areas nearby. The number of tick species on birds is different for particular migration routes. In the Scandinavian region one species-I. ricinus is dominant, however other species were found on migratory birds (individual cases)—Hyalomma 
rufipes, I. arboricola, I. frontalis, Dermacentor sp. (Hasle 2013; Comstedt et al. 2006), I. lividus (Comstedt et al. 2006). In Central Europe, where migration routes cross, I. ricinus still dominates and other species are also recorded: I. frontalis, I. arboricola, I. eldaricus (Nowak-Chmura et al. 2012), H. marginatum (Siuda and Dutkiewicz 1979), I. festai (Siuda and Szymański 1991), D. reticulatus (present study), H. punctata (Lachmajer et al. 1956; present study). In Western Europe and in the Western Mediterranean basin however, the most frequently occurring tick species on birds is $H$. marginatum. Other species were recorded in lower numbers: I. ventalloi, I. frontalis, Rh. turanicus, H. punctata, I. ricinus (Oscar-Jimenez et al. 1998; Santos-Silva et al. 2006). In Morocco 8 ticks species were observed on birds: $H$. marginatum, $H$. aegyptium, $R$. turanicus, $H$. punctata, I. festai, I. ricinus, I. frontalis, Argas persicus (Bailly-Choumara et al. 1976; Palomar et al. 2016). On the eastern migratory route in Hungary I. ricinus, H. punctata and Hyalomma sp. were found on birds during migration (Hornok et al. 2014a, b). In the Danube Delta I. ricinus was dominant, however I. arboricola, I. redikorzevi and H. punctata also occurred (Sándor et al. 2014), in Greece I. frontalis, I. acuminatus, H. aegyptium and H. marginatum were recorded (Diakou et al. 2016). In Egypt and Cyprus detailed research by Nuorteva and Hoogstraal (1963), Hoogstraal et al. (1963, 1964), Kaiser et al. (1974) indicated that birds are able to transport at least 13 ticks species $H$. rufipes, A. variegatum, Ixodes spp. I. ricinus, I. frontalis, I. redikorzevi, $H$. punctata, $H$. sulcata, H. inermis, $H$. aegyptium, H. marginatum, H. anatolicum, H. excavatum, H. dromedarii. In the South Africa region, there is still a lack of information on ticks of migratory birds. Ticks function as reservoirs of pathogenic microorganisms (Nowak-Chmura 2013). Thus the potential of pathogens to spread between geographical regions is real.

Adult ticks very rarely attack birds (one case of a I. ricinus adult male on E. rubecula in the present study). Adult ticks occasionally parasitize migratory birds, which has been observed at other ringing stations on the Western and Eastern European migratory routes (Nuorteva and Hoogstraal 1963; Hoogstraal et al. 1964; Mikula et al. 2011). Other Polish studies from the Baltic coast also confirm sporadic adult ticks during spring migration, e.g. one female of I. arboricola and 2 females and one male I. eldaricus (Nowak-Chmura 2012).

The total prevalence of tick infestation from 2011 to 2012 at Wicie ringing station, Poland, was $40.7 \%$ in spring and $40.0 \%$ in autumn. Similar levels of infestation have been recorded in other Western and Eastern bird migration routes in Europe (Nuorteva and Hoogstraal 1963; Hoogstraal et al. 1964; Kahl 1971; Kaiser et al. 1974; Walter et al. 1979; Osacar-Jimenez et al. 1998; Comstedt et al. 2006; Mikula et al. 2011; Nowak-Chmura et al. 2012; Movila et al. 2013; Sándor et al. 2014; Ciebiera et al. 2014). The tick prevalence on migratory birds on the Polish Baltic coast has increased from $31 \%$ in spring and $22 \%$ in autumn since 1981 (Nowak-Chmura et al. 2012). This increase may be directly related to climate change in Central Europe. Recent studies show that the range of I. ricinus has extended to $66^{\circ} \mathrm{N}$ latitude in Sweden from $61^{\circ} \mathrm{N}$ since the end of the twentieth century (Gray et al. 2009).

In case of the Polish Baltic coast, the ground feeding, medium distant and night migrating birds are the most important hosts for the majority ticks of all developmental stages. In addition, ground feeding birds have a five times higher prevalence of ticks than other bird groups. According to Biernat et al. (2016) ground feeding birds are responsible for ticks infected with Rickettsia sp., while similar results by Gryczyńska and Wlec-Falęciak (2016), indicated that blackbirds played an important role as carriers of ticks infected with Borrelia burgdorferi s.l. genospecies in the natural environment. 
The highest prevalence of larvae was observed during autumn migration while nymphal stages were highest during spring migration. These differences were statistically significant. A similar situation has been observed by other authors (Nuorteva and Hoogstraal 1963; Kahl 1971; Walter et al. 1979; Špitalská et al. 2006; Nowak-Chmura et al. 2012). The high proportion of larvae during autumn migration can be explained by the annual life cycle of I. ricinus ticks. Larvae appear in the habitat after a spring peak of adult activity. The majority of these larvae then moult into nymphs before winter and nymphs then find another host in spring.

We analyzed the prevalence of ticks in males and females from selected bird species. Only Blackbird T. merula males had more ticks than females, both, during spring and autumn migration (the difference was statistically significant at the 5\% level). This is the first time that this has been described in literature. The blackbird is a ground feeding bird, which forages for earthworms, insects and larvae and other invertebrates, but also fruits and seeds (del Hoyo et al. 2017). Sex differences in prevalence could be explained by differences in feeding strategies between the sexes in this species. Further study in this area is required.

All ticks were located on the birds' heads, especially on the corners of the beak and on eye ring and occasionally on the neck and inside the beak. The delicate, unfeathered skin in the corners of the beak is very well supplied with blood. Moreover, birds cannot remove these ticks using beak or claws. Many other authors confirm the highest occurrence of ticks in the beaks corners during their studies (Hasle et al. 2009; Nowak-Chmura et al. 2012; Sándor et al. 2014).

In conclusion, our study results highlight the significant role of migratory birds in tick dispersal on migratory routes and indicate its epidemiologic importance in the natural environment. Transport of ticks by migratory birds is a common event especially for the ground feeding, medium distant and night migrating species.

Acknowledgements We are grateful to the "Fundacja Wspierania Badań nad Wędrówkami Ptaków" for support in field works and Prof. Brendan Kavanagh for the language editing of the manuscript.

\section{Compliance with ethical standards}

Ethical approval All applicable international, national, and/or institutional guidelines for the care and use of animals were followed. Bird ringing was carried out under license from the General Director of Environmental Protection in Poland. No approval was required for the removal of ticks according to Polish law. Anesthesia, euthanasia, or any other kind of animal sacrifice was not a part of the study.

Open Access This article is distributed under the terms of the Creative Commons Attribution 4.0 International License (http://creativecommons.org/licenses/by/4.0/), which permits unrestricted use, distribution, and reproduction in any medium, provided you give appropriate credit to the original author(s) and the source, provide a link to the Creative Commons license, and indicate if changes were made.

\section{References}

Bailly-Choumara H, Morel PC, Rageau J (1976) Sommaire des données actuelles sur les tiques du Maroc (Acari, Ixodoidea). Inst Scient 1:101-117

Berthold P (2001) Bird migration: a general survey. Oxford University Press, Oxford

Biernat B, Stańczak J, Michalik J, Sikora B, Cieniuch S (2016) Rickettsia helvetica and R. monacensis infections in immature Ixodes ricinus ticks derived from sylvatic passerine birds in west-central Poland. Parasitol Res 115:3469-3477. https://doi.org/10.1007/s00436-016-5110-6 
Busse P (1984) Key to sexing and ageing of European passerines. Beitr Naturk Niedersachsens 37, Suppl

Busse P (2000) Bird station manual. University of Gdańsk Press, Gdańsk

Busse P (2005) Polskie badania wędrówek ptaków. Skąd wyszliśmy i dokąd zmierzamy, in: Nowakowski JJ, Tryjanowski P, Indykiewicz P (2005) Proc. Ornitol. Pol. Progu XXI stulecia. Dokonania i perspektywy. Conference. Olsztyn. pp 87-101

Ciebiera O, Jerzak L (2011) Tick numbers on migratory birds - preliminary data from the Polish Baltic. Coast Fol Oecol 6:26-30

Ciebiera O, Bensusan K, Perez C (2014) Ticks (Ixodidae) on migratory birds during spring migration 2013 via Strait of Gibraltar: preliminary data. Arthropods. Invasions and their control. Koliber, Lublin, pp 117-125DOM2016

Comstedt P, Bergström S, Olsen B, Garpmo U, Marjavaara L, Mejlon H et al (2006) Migratory passerine birds as reservoirs of Lyme borreliosis in Europe. Emerg Infect Dis 12:1087-1095

Daniel M, Černý V, Honzáková E, Olejniček J (1977) Possibilities of persistence in new biotopes of ticks imported by birds. Folia Parasitol 24:47-54

del Hoyo J, Elliott A, Sargatal J, Christie DA, de Juana E (eds) (2017) Handbook of the Birds of the World Alive. Lynx Edicions, Barcelona. http://www.hbw.com/. Accessed 10 October 2017

Diakou A, Norte A, Lopes de Carvalho I, Núncio S, Nováková M, Kautman M et al (2016) Ticks and tickborne pathogens in wild birds in Greece. Parasitol Res 115:2011-2016. https://doi.org/10.1007/s0043 6-016-4943-3

Fuller T, Bensch S, Müller I, Novembre J, Pérez-Tris J, Ricklefs RE, Smith TB, Waldenström J (2012) The ecology of emerging infectious diseases in migratory birds: an assessment of the role of climate change and priorities for future research. Ecohealth 9:80-88

Gray JS, Dautel H, Estrada-Peña A, Kahl O, Lindgren E (2009) Effects of climate change on ticks and tickborne diseases in Europe. Interdiscip Perspect Infect Dis. https://doi.org/10.1155/2009/593232

Gryczyńska A (2002) Prevalence of Borrelia burgdorferi sensu lato spirochaetes in some passerine bird species from north-eastern Poland. Int J Med Microb 291:204-204. https://doi.org/10.1016/S1438 $-4221(02) 80048-0$

Gryczyńska A, Welc-Falęciak R (2016) Long-term study of the prevalence of Borrelia burgdorferi s.l. infection in ticks (Ixodes ricinus) feeding on blackbirds (Turdus merula) in NE Poland. Exp Appl Acarol 70:381-394

Hasle G (2013) Transport of ixodid ticks and tick-borne pathogens by migratory birds. Front Cell Infect Microbiol 3:48. https://doi.org/10.3389/fcimb.2013.00048

Hasle G, Bjune G, Edvardsen E, Jakobsen C, Linnehol B, Røer JE, Mehl R et al (2009) Transport of ticks by migratory passerine birds to Norway. J Parasitol 95:1342-1351

Hasle G, Leinaas HP, Røed KH, Øines Ø 2011 Transport of Babesia venatorum-infected Ixodes ricinus to Norway by northward migrating passerine birds. Acta Vet Scand 53:41-45

Hoogstraal H, Kaiser MN, Traylor MA, Guindy E, Gaber S (1963) Ticks (Ixodidae) on birds migrating from Europe and Asia to Africa, 1959-61. Bull World Health Organ 28:235-262

Hoogstraal H, Traylor MA, Gaber S, Malakatis G, Guindy E, Helmy I (1964) Ticks (Ixodidae) on migrating birds in Egypt, Spring and Fall 1962. Bull World Health Organ 6:355-367

Hornok S, Kováts D, Csörgő T, Meli ML, Gönczi E, Hadnagy Z, Takács N, Farkas R, Hofmann-Lehmann R (2014a) Birds as potential reservoirs of tick-borne pathogens: first evidence of bacteraemia with $R$. helvetica. Parasit Vectors 7:128

Hornok S, Kováts D, Csörgő T, Meli ML, Gönczi E, Hadnagy Z, Takács N, Farkas R, Hofmann-Lehmann $\mathrm{R}$ (2014b) Birds as potential reservoirs of tick-borne pathogens: first evidence of bacteraemia with $R$. helvetica. Parasit Vectors 7:128. https://doi.org/10.1186/1756-3305-7-128

Kahl K (1971) Some observations on the occurrence of Ixodes ricinus (L.) living on migratory birds. Wiad Parazytol 17:417-426

Kaiser MN, Hoogstraal H, Watson GE (1974) Ticks (Ixodoidea) on migrating birds in Cyprus, fall 1967 and spring 1968, and epidemiological considerations. Bull Entomol Res 64:97-110. https://doi. org/10.1017/S0007485300027024

Kjelland V, Stuen S, Skarpaas T, Slettan A (2010) Borrelia burgdorferi sensu lato in Ixodes ricinus. ticks collected from migratory birds in southern Norway. Acta Vet Scand 6:52-59. https://doi. org/10.1186/1751-0147-52-59

Laakkonen J, Terhivuo J, Huhtamo E, Vapalahti O, Uzcátegui NY (2009) First report of Ixodes frontalis (Acari: Ixodidae) in Finland, an example of foreign tick species transported by a migratory bird. Memoranda Societatis pro Fauna et Flora Fennica 85:16-19

Lachmajer J, Skierska B, Wegner Z (1956) Ticks Haemaphysalis Koch (Ixodidae) found in Poland. Bull State Inst Mar Trop Med Gdańsk 7:189-195 [in polish] 
Mikula P, Hromada M, Koleničová A, Pjencak P, Fulín M, Olekšák M (2011) Ticks of avian migrants in the Slovak Krast. Acta Universitatis Presoviensis Folia oecologica 5:56-64

Movila A, Alekseev AN, Dubinina HV, Toderas I (2013) Detection of tick-borne pathogens in ticks from migratory birds in the Baltic region of Russia. Med Vet Entomol 27(1):113-117

Newton I (2008) The migration ecology of birds. Elsevier, London

Nowak M, Siuda K, Solarz K, Góra A, Cuber P (2009) A risk of infection with ticks of Ixodes ricinus (Linnaeus, 1798) species (Acari: Ixodidae) in south-eastern Poland depending on the daily and seasonal rhythm. In: Buczek A, Błaszak C (eds) Arthropods. Invasions and their control. Koliber, Lublin pp. $31-45$

Nowak-Chmura M (2012) Ixodes eldaricus Djaparidze. 1950 (Ixodidae) on migrating birds-reported first time in Poland. Vet Parasitol 186(3-4):399-402

Nowak-Chmura M (2013) Fauna kleszczy (Ixodida) Europy Środkowej. Wyd Nauk Uni Ped, Kraków

Nowak-Chmura M, Siuda K, Piksa K (2012) Species diversity of ticks (Acari: Ixodida) on migrating birds on the Baltic Sea coast of Poland. Zool Stud 51:1411-1417

Nuorteva P, Hoogstraal H (1963) The incidence of ticks (Ixodoidea, Ixodidae) on migratory birds arriving in Finland during the spring of 1962. Ann Med Exp Biol Fenn 41:457-468

Osacar-Jimenez JJ, Estrada-Pena A, Lucientes-Curdi J (1998) Ticks (Acarina: Ixodidae) of wild birds in the Ebro middle basin (North-East Spain). Acarologia 39:23-31

Palomar AM, Portillo A, Mazuelas D, Roncero L, Arizaga J, Crespo A et al (2016) Molecular analysis of Crimean-Congo hemorrhagic fever virus and Rickettsia in Hyalomma marginatum ticks removed from patients (Spain) and birds (Spain and Morocco), 2009-2015. Ticks Tick Borne Dis 7:983-987. https:// doi.org/10.1016/j.ttbdis.2016.05.004

Sándor AD, Mărcuţan DI, D’Amico G, Gherman CM, Dumitrache MO et al (2014) Do the ticks of birds at an important migratory hotspot reflect the seasonal dynamics of Ixodes ricinus at the migration initiation site? A case study in the Danube Delta. PLoS ONE 9(2):e89378. https://doi.org/10.1371/journ al.pone. 0089378

Santos-Silva MM, Sousa R, Santos AS, Melo P, Encarnação V, Bacellar F (2006) Ticks parasitizing wild birds in Portugal: detection of Rickettsia aeschlimannii, R. helvetica and R. massiliae. Exp Appl Acarol 39:331-338

Siuda K (1993) Kleszcze Polski (Acari: Ixodida). Część II. Systematyka i rozmieszczenie. PTP, Warsaw

Siuda K, Dutkiewicz J (1979) Hyalomma marginatum Koch, 1844 (Acarina: Ixodidae) w Polsce - przykład zawleczenia południowego kleszcza przez ptaki wędrowne. Wiad Parazytol 25:333-338

Siuda K, Szymański S (1991) Przypadek zawleczenia do Polski przez ptaki wędrowne śródziemnomorskiego kleszcza Ixodes (Ixodes) festai Rondelli, 1926 (Acari: Ixodida: Ixodidae). Wiad Parazytol 37:5-29

Špitalská E, Literàk I, Sparagano OA, Golovchenko M, Kocianovà E (2006) Ticks (Ixodidae) from passerine birds in the Carpathian region. Wien Klin Wochenschr 118:759-764

Svensson L (1992) Identification guide to European Passerines. BTO, Stockholm

Swiss Ornithological Institute (2018) http://www.vogelwarte.ch/. Accessed 10 Sep 2017

Walter G, Liebisch A, Vauk G (1979) Studies on the biology and distribution of ticks (Ixodoidea, Ixodidae) in North Germany. II. Tick infestation of migrating birds on the island Heligoland. Z Angew Zool 66:445-461

Zaniewicz G, Rosińska K (2015) The Wicie Ringing Station (N POLAND)—ringing results and seasonal bird migration dynamics in 2010-2014. The Ring 37:55-64. https://doi.org/10.1515/ring-2015-0003

Zar JH (1999) Biostatystical analysis, 4th edn. Presence Hall, New Jersey

Publisher's Note Springer Nature remains neutral with regard to jurisdictional claims in published maps and institutional affiliations. 